\title{
Fertilization with nitrogen and potassium on pastures in temperate areas
}

\author{
MARÍA ROSA MOSQUERA-LOSADA, ANTONIO GONZÁLEZ-RODRIGUEZ, AND ANTONIO RIGUEIRO \\ RODRÍGUEZ
}

Authors are Researcher, Crop Production Department, Escuela Politécnica Superior, University Santiago de Compostela, 27002-Lugo, Principal Researcher in Milk Production of the Agrarian Research Centre of Mabegondo. 15080. A Coruña, and Professor, Crop Production Department, Escuela Politécnica Superior, University Santiago de Compostela, 27002-Lugo.

\begin{abstract}
Fertilizer application enable producers to influence pasture production. The effect of $\mathbf{N}$ fertilization on grass production and leguminous plant content of pasture and strategic $\mathbf{N}$ application has received much attention. Changing agricultural policies suggest that chemical fertilizer inputs may be diminished and that alternative sources of nutrients are desired. The aim of this study was to evaluate the effect of $N$ and $K$ fertilization on production, botanical composition, and forage mineral composition to gain some insight into what influence changing fertilization practices would have on pasture productivity. Three $\mathrm{K}$ and $3 \mathbf{N}$ application rates were applied in a factorial design on a white clover (Trifolium repens L.)-perennial ryegrass (Lolium perenne L.) sward. Potassium and nitrogen application increased herbage production and had differential influences on botanical composition. Nitrogen decreased clover content in the pasture, whereas $K$ increased the proportion and production of white clover. The effects of $K$ application appeared later in the experiment than those associated with $N$. We concluded that $K$ is very important for development and maintenance of white clover in pasture, which increases herbage and protein production. Nitrogen was associated with lesser amounts of $\mathrm{N}, \mathrm{P}, \mathrm{K}$, and $\mathrm{Mg}$ in pasture, because of lesser amounts of clover in the sward. Changing fertilization practices will have definite influences on sward composition and pasture productivity. Any interpretation of pasture mineral content should take botanical composition changes into account.
\end{abstract}

Key Words: clover, nutrient, botanical composition

Nitrogen fertilization, the main technique controlled by the farmer to influence herbage production, has been studied for many years. The response of grass production (González 1992, González et al. 1996) botanical composition (González 1988) to $\mathrm{N}$ fertilization, and strategic $\mathrm{N}$ application (Mosquera et al. 1992) was reported for northwestern Spain and for regions with similar climatic conditions. Inorganic nitrogen fertilizers can damage the environment when applied in large amounts (González et al. 1996), suggesting that ecologically benign sources of $\mathrm{N}$ should be considered for agricultural systems.

Research was funded in part by Agricultural, Food and Fisheries National Ministry and by Agricultural and Fisheries Galician Regional Ministry. 111

Manuscript accepted 19 Jul. 03.

\section{Resumen}

La fertilización es una práctica de manejo que permite a los ganaderos modificar la producción de pasto. Por este motivo, el efecto de la fertilización nitrogenada y su aporte estratégico sobre la producción y el contenido de leguminosas del pasto ha sido estudiado en numerosas ocasiones. La política agraria actual promueve la utilización de fuentes alternativas a los fertilizantes inorgánicos, limitando su aporte. El objetivo de este estudio fue evaluar el efecto de la fertilización nitrogenada y potásica sobre la producción, composición botánica y mineral para determinar la influencia del cambio de las prácticas de fertilización sobre la capacidad productiva del pasto. Los tratamientos consistieron en la aplicación de 3 dosis de potasio y 3 de nitrógeno en un diseño factorial sobre una pradera de raigrás inglés (Lolium perenne $\mathrm{L}_{\text {.) }}$ y trébol blanco (Trifolium repens $\mathrm{L}_{\text {.). }} \mathrm{El}$ aporte de potasio y nitrógeno incrementó la producción de hierba y ocasionó diferencias en la composición botánica. La aplicación de nitrógeno redujo el contenido de trébol en el pasto, mientras que la de potasio aumentó la producción y proporción de trébol. Los efectos de la aplicación de potasio aparecían más tarde que los debidos al nitrógeno. Se concluye que el potasio es muy importante para el desarrollo y mantenimiento del trébol blanco en el pasto, el cual incrementa la producción de hierba y proteína. El aporte de nitrógeno provocó una reducción de $\mathbf{N}, \mathbf{P}, \mathrm{K}$ y Mg en el pasto, debido a la menor presencia de trébol. El cambio de las prácticas de fertilización modificará la composición y capacidad productiva del pasto. Las interpretaciones sobre el contenido mineral del pasto deberían tener en cuenta las modificaciones sobre la composición botánica.

Atmospheric $\mathrm{N}$ introduced into the soil by symbiotic Rhizobia is positively related to legume content in pasture, resulting in improved pasture production (Frame and Newbould 1984). The percentage of clover is related to protein production, leading to better pasture nutritive value. Clover content in pasture is inversely related to $\mathrm{N}$ fertilization (Meister and Lehmann 1985, Chapman et al. 1996), and positively with the K (Rodríguez and Pinto 1987, Simpson et al. 1988). Pasture fertilization influences nutrient availability in soil or modifies relationships with other elements in the soil, increases pasture growth, and as a result causes changes in nutrient bioavailability where soil $\mathrm{pH}$ is modified (Chevalier 1981, Frame 1990, Whitehead 1995, Chapman et al. 1996, Clark and Harris. 1996). 
Moreover, fertilization can influence the ecological advantages of some species with respect to others, because of differential responses to mineral nutrient supply. The progressive reduction of fertilizer inputs resulting from European Union agrarian policy will modify botanical composition of pastures and increase forb species that usually have a greater mineral content than found in widely grown grasses such as perennial ryegrass (Babnik et al. 1996). This should be considered when developing mineral supplementation strategies for animal feeding. Understanding the influence of fertilization strategies on the botanical and mineral composition of pasture will help farmers determine the type and quantity of supplement that should be provided to grazing livestock to optimise performance.

The objective of our experiment was to determine the influence of combinations of $\mathrm{N}$ and $\mathrm{K}$ fertilization on herbage production, sward botanical composition and chemical composition of a grass-clover pasture during a 4-year period.

\section{Materials and Methods}

The experiment was conducted in the northwest of Spain (Galicia) from 1989 through 1992, in Mabegondo (A Coruña, $43^{\circ} 15^{\prime} \mathrm{N}$ lat.; $8^{\circ} 18^{\prime} \mathrm{W}$ long. at $100 \mathrm{~m}$ above sea level). The pasture was sown in autumn of 1988 with a mixture of $25 \mathrm{~kg}$ $\mathrm{ha}^{-1}$ of perennial ryegrass (Lolium perenne L.) cv. Brigantia and $3 \mathrm{~kg} \mathrm{ha}^{-1}$ of white clover (Trifolium repens var. Huia on a sandy-loam soil, with an average $\mathrm{pH}$ of 6.08 , low available $\mathrm{P}$ (15 p pm) and medium available $\mathrm{K}(87 \mathrm{ppm})$ prior to fertilizing. The rate of $\mathrm{P}_{2} \mathrm{O}_{5}$ application was $90 \mathrm{~kg} \mathrm{ha}^{-1}$ in the autumn of 1988 and $150 \mathrm{~kg} \mathrm{ha}^{-1}$ annually in spring each year. Mean temperature and precipitation at the site are presented in Table 1.

Table 1. Mensual mean temperature $\left(\mathrm{T},{ }^{\circ} \mathrm{C}\right)$ and rainfall $(\mathrm{Pp}, \mathrm{mm})$ per month in $1989,1990,1991$, and 1992.

\begin{tabular}{|c|c|c|c|c|c|c|c|c|c|c|c|c|}
\hline Month & $\mathrm{J}$ & $F$ & $\mathbf{M}$ & A & My & $\mathrm{Jn}$ & $\mathrm{Jl}$ & $\mathrm{Au}$ & $S$ & 0 & $\mathrm{~N}$ & D \\
\hline $\bar{T}$ & & & & & & ( & ......... & - & - & - & - & -.-- \\
\hline 1989 & 7.6 & 8.8 & 9.9 & 9.4 & 16.0 & 16.8 & 19.6 & 19.3 & 16.8 & 15.3 & 11.9 & 11.5 \\
\hline 1990 & 8.1 & 11.7 & 10.9 & 9.9 & 15.1 & 15.6 & 19.4 & 19.0 & 18.2 & 13.9 & 9.7 & 6.7 \\
\hline 1991 & 7.4 & 7.0 & 9.8 & 10.0 & 13.6 & 14.9 & 18.0 & 19.3 & 18.2 & 12.0 & 10.3 & 8.9 \\
\hline 1992 & 5.8 & 5.2 & 9.6 & 11.1 & 15.0 & 14.5 & 18.0 & 17.7 & 15.0 & 11.2 & 12.7 & 8.8 \\
\hline $\mathrm{Pp}$ & & & & & 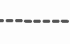 & $---(1$ & ))--- & - & 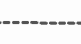 & & & \\
\hline 1989 & 31 & 149 & 67 & 133 & 51 & 18 & 11 & 19 & 6 & 95 & 134 & 32 \\
\hline 1990 & 96 & 74 & 14 & 100 & 33 & 20 & 13 & 8 & 20 & 200 & 151 & 114 \\
\hline 1991 & 157 & 140 & 86 & 64 & 20 & 22 & 67 & 56 & 118 & 84 & 136 & 17 \\
\hline 1992 & 75 & 13 & 98 & 49 & 45 & 67 & 3 & 92 & 92 & 99 & 101 & 103 \\
\hline
\end{tabular}

Treatments were applied in a split-plot design with 4 replicates ( 2 by $5 \mathrm{~m}^{2}$ plots) of each treatment combination. Main plots were $\mathrm{N}$ at $0(\mathrm{~N} 1), 60(30+30)(\mathrm{N} 2)$, and $120(60+60)(\mathrm{N} 3) \mathrm{kg} \mathrm{N}^{-1}$ applied between 23 February and 7 March, with the second application made after the second cut. Each $\mathrm{N}$ treatment had $3 \mathrm{~K}$ application rates of $0(\mathrm{~K} 1), 100(50+50)$ (K2) and $200(100+100)(\mathrm{K} 3) \mathrm{kg} \mathrm{K}_{2} \mathrm{O}$ $\mathrm{ha}^{-1}$ applied at the same time as $\mathrm{N}$.

Cutting times are presented in Table 2. A 4 by $0.9 \mathrm{~m}^{2}$ area was sampled for fresh

Table 2. Harvest cutting dates during the 4 studied years.

\begin{tabular}{lcrrr}
\hline \hline Cut & 1989 & 1990 & 1991 & 1992 \\
\hline First & $6 / 4$ & $3 / 4$ & $15 / 4$ & $2 / 4$ \\
Second & $5 / 5$ & $7 / 5$ & $3 / 5$ & $4 / 5$ \\
Third & $9 / 6$ and & $28 / 6$ & $26 / 6$ & $13 / 8$ \\
& $28 / 7$ & & & \\
Fourth & $28 / 12$ & $21 / 12$ & $22 / 12$ & $20 / 12$ \\
\hline
\end{tabular}

and dry mass from each plot, and a subsample (100 g) was dried for 18 hours at $80^{\circ} \mathrm{C}$, ground and used for chemical composition analyses. Botanical composition was determined by hand separation of species from $100 \mathrm{~g}$ fresh samples.

Micro-kjeldahl digestion was used to determine crude protein (CP) and phosphorus content (Castro et al. 1990). Mineral element contents of herbage were determined by atomic absorption spectroscopy (Perkin-Elmer 460).

Herbage mass, protein, $\mathrm{P}, \mathrm{Ca} \mathrm{K}, \mathrm{Mg}$, $\mathrm{Cu}, \mathrm{Fe}, \mathrm{Zn}$, and $\mathrm{Mn}$ content of pasture and sown grass, sown legumes and other species were analysed in 2 years period: 1989-1990 and 1991-1992 using ANOVA and significant means separated by LSD testing.

\section{Results}

\section{Climate}

Mean temperature and rainfall for all 4 years are presented in Table 1. There was an unusually prolonged summer drought in 1989, lasting from June through October. March 1990 was unusually dry, and December of the same year unusually cold.

January and February, as well as the autumn of 1991 and 1992, were colder months than usual. April and May of 1991 were drier than usual, and, finally, July, August and September of 1991 had more rain than average. August of 1992 was wetter than normal.

\section{Soil Analysis}

Soil analysis, at the end of the experiment, can be seen in Table 3. No N effects were found on different soil parameters. However, increase of fertilization with $\mathrm{K}$ significantly raised the level of $\mathrm{K}$ and reduced the level of $\mathrm{Na}$ in soil.

\section{Nitrogen fertilization effect}

Dry matter increased when $30 \mathrm{~kg} \mathrm{~N}^{-1}$ applied for first cuttings was positive in the first and fourth year (Fig. 1), but no effect was found in the other years due probably to climatic conditions. No residual effect of this $\mathrm{N}$ application was found in the second cutting.

Only in the first year production was positively related to $\mathrm{N}$ application. Negative responses to $N$ in 1990 and 1991 and no response at all in 1992 were recorded. Spring $\mathrm{N}$ application, did not affect autumn production, despite the differences of clover content of pasture (Table 4). Dry matter production per $\mathrm{kg}$ of fertilizer applied can be seen in Table 5. Response to $\mathrm{N}$ was different every year for the potassium applications, being somewhat less in the latter years, with the exception of high $\mathrm{N}$ application to a medium potassium dose where annual production response to $\mathrm{N}$ fertilization was increasing with the years.

Botanical composition: White clover production for each treatment is presented in Fig. 2. There were no significant amounts of clover in the 2 first harvests of 1989 and 1991. Increasing $\mathrm{N}$ doses reduced clover production in all spring harvests, with the exception of autumn, when no effect was seen. Differences between treatments as well as clover content were, in all 4 years, greater in the last spring cut, as weather conditions were 
Table 3. Soil analysis at the end of the experiment of plots with different nitrogen doses $(\mathrm{N} 1=0, \mathbf{N} 2$ $=30+30$ and $\mathrm{N} 3=60+60 \mathrm{~kg} N / \mathrm{ha})$ and potassium doses $(\mathrm{K} 1=0, \mathrm{~K} 2=50+50$ and $\mathrm{K3}=100+$ $100 \mathrm{~kg} \mathrm{~K}$ O/ha).

\begin{tabular}{lrrrlcccc}
\hline \hline & \multicolumn{4}{c}{ Treatment } & \multicolumn{4}{c}{ Treatment } \\
& N1 & N2 & N3 & Sig. & K1 & K2 & K3 & Sig. \\
\hline $\mathrm{pH}$ & 6.00 & 6.17 & 6.07 & $\mathrm{~ns}$ & 6.19 & 6.06 & 6.01 & $\mathrm{~ns}$ \\
$\% \mathrm{Al}$ & 0.55 & 0.09 & 0.20 & $\mathrm{~ns}$ & 0.11 & 0.32 & 0.35 & $\mathrm{~ns}$ \\
$\mathrm{Ca}$ & 5.57 & 6.17 & 5.92 & $\mathrm{~ns}$ & 6.20 & 5.75 & 5.70 & $\mathrm{~ns}$ \\
$\mathrm{~K}$ & 44.17 & 48.50 & 54.33 & $\mathrm{~ns}$ & $41.17 \mathrm{a}$ & $43.00 \mathrm{a}$ & $62.83 \mathrm{~b}$ & $*$ \\
$\mathrm{Mg}$ & 0.65 & 0.71 & 0.71 & $\mathrm{~ns}$ & 0.72 & 0.69 & 0.66 & $\mathrm{~ns}$ \\
$\mathrm{Na}$ & 0.32 & 0.31 & 0.31 & $\mathrm{~ns}$ & $0.34 \mathrm{a}$ & $0.30 \mathrm{~b}$ & $0.30 \mathrm{~b}$ & $* *$ \\
Pasim & 12.95 & 13.13 & 14.47 & $\mathrm{~ns}$ & 13.10 & 13.22 & 14.23 & $\mathrm{~ns}$ \\
\hline
\end{tabular}

***: $\mathrm{P}<0.001 ; * *: \mathrm{P}<0.01 ; *: \mathrm{P}<0.05$ advantageous for clover growth. The effect of $\mathbf{N}$ Fertilization on clover production was reduced in the 2 last years, in comparison with clover content values in the treatments in the 2 first years.

The proportion of sown species (Lolium perenne and Trifolium repens) and adventitious ones in the periods 1989-1990 and 1991-1992 are shown in Table 4. The percentage of sown species was gradually reduced from approximately $70 \%$, in the period $1989-90$. to approximately $40 \%$, in the period 1991-1992. The proportion of Lolium was higher in the treatment fertilised with $\mathrm{N}$ in 1989-1990. However, the percentage of that species was significantly higher in non-fertilised treatments in the second 2 year period.

No $N$ effects were found in the proportion of spontaneous species, with the exception of the second sample from the 1991-1992 period, in that cutting, in the treatment $\mathrm{N} 2$, the presence of adventitious plants was reduced; due to the better development of Lolium in low or medium doses of $\mathrm{N}$ treatment. Generally, $\mathbf{N}$ fertilization affected the proportion of Lolium and Trifolium in the pasture, but did not affect the overall percentage of the sown species in pasture.

\section{Protein, Macro-element and Micro- element contents of the pasture}

Crude protein in the 2 periods studied is shown in Table 6. Protein percentage was generally higher in pasture from low $\mathrm{N}$ doses plots, in the year overall related with a high clover content, but the reverse situation was found in autumn of the 1991-1992 period, when there was also a high clover content in plots fertilised with the higher amounts of $\mathrm{N}$ ( $60 \mathrm{~kg} \mathrm{~N} / \mathrm{ha}$ ).

The phosphorus, potassium, calcium and magnesium content of pasture in each treatment are shown in Tables 7, 8, 9, and 10 , respectively. Higher phosphorus content of pasture was found in plots where there was no fertilization treatment, in the overall period and in the second cutting of 1989-1990, and in the third harvest of 1991-1992, affected probably by clover content.

The application of $\mathrm{N}$ had a negative effect on the potassium content of pasture in each period studied, in the second cutting of the 1989-1990 period, and in the third cutting of the 1991-1992 period, although the same tendency was found in nearly all cuttings studied.

The calcium percentage of pasture was lower in pasture fertilised with higher levels of $\mathbf{N}$, but the opposite was found in the autumn 1989-1990 periods. No effect was found in the 1991-1992 period.

The magnesium percentage of pasture is shown in Table 10. Magnesium content was negatively affected by $\mathrm{N}$ fertilization in the autumn of 1989-1990 period probably due to a higher content of clover in this cut, but the opposite was found in the third harvest of 1991-1992. In the periods studied overall, there was no effect on potassium content in pasture of fertilization with $\mathrm{N}$ and potassium

Zinc, copper, iron, and manganese content of pasture is presented in Tables $11,12,13$, and 14 , respectively. There was no clear answer to $\mathrm{N}$ fertilization in $\mathrm{Zn}$ pasture content. The results were positive and negative in the second and third harvests of the 1989-1990 period, respectively. No effect was found in the other cuts. No response to $\mathrm{N}$ fertilization was found in $\mathrm{Cu}, \mathrm{Fe}$, and $\mathrm{Mn}$ contents with the exception of a positive response with regard to $\mathrm{Mn}$ concentration in the second harvest of the 1991-1992 period.

\section{Protein and potassium outputs}

Protein and $\mathrm{K}$ pasture content $(\mathrm{kg} / \mathrm{ha})$ for all treatments, is presented in Tables 15 and 16, respectively. Nitrogen fertilization had a positive effect on protein production in the first and second cutting, in 1989, in the second harvest in 1990 , and in the first cutting in 1991. In some cuttings, normally the last ones, $\mathrm{N}$ fertilization had no effect or even negative effect, probably due to a variation of clover content when $\mathrm{N}$ is applied to the soil. Nitrogenous fertilization had a

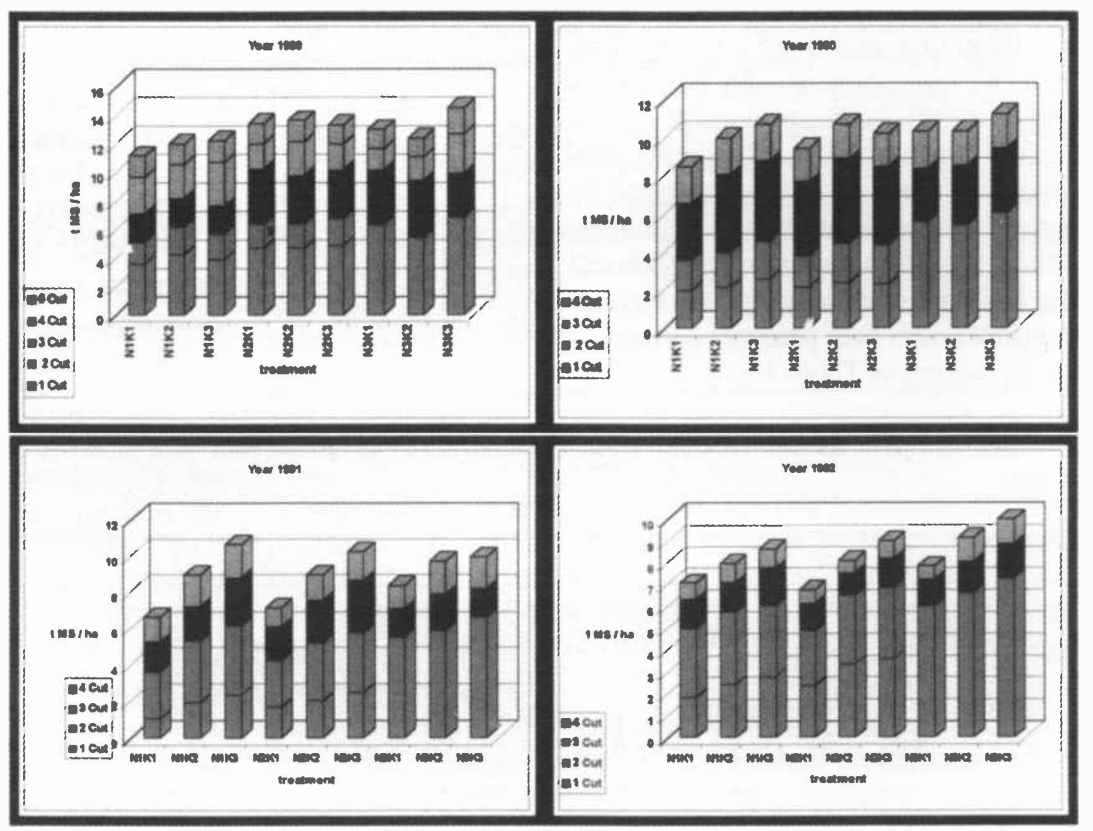

Fig. 1. Pasture production (t/ha) under different treatments at different cutting dates in 1989, 1990, 1991, and $1992\left(\mathrm{~N} 1: 0 \mathrm{~kg} \mathrm{~N} \mathrm{ha}{ }^{-1} ; \mathrm{N} 2: 60 \mathrm{~kg} \mathrm{~N} \mathrm{ha}^{-1}(30+30) ; \mathrm{N3}: 120 \mathrm{~kg} \mathrm{~N} \mathrm{ha}^{-1}(60+\right.$ 60); K1: $0 \mathrm{~kg} \mathrm{~K}_{2} \mathrm{O} \mathrm{ha}{ }^{-1}$; K2: $100 \mathrm{~kg} \mathrm{~K}_{2} \mathrm{O} \mathrm{ha}{ }^{-1}(50+50)$ and K3: $200 \mathrm{~kg} \mathrm{~K}_{2} \mathrm{O} \mathrm{ha}^{-1}(100+$ 100)). 
Table 4. Percentages of sown grass, clover, and other species in each treatment and in the periods 1989-1990 and 1991-1992.

\begin{tabular}{|c|c|c|c|c|c|c|c|c|}
\hline \multicolumn{9}{|c|}{ Grass } \\
\hline Grass & No & N30 & N60 & Sig & K0 & K50 & $\mathrm{K} 100$ & Sig. \\
\hline$\overline{1989-1990}$ & \multicolumn{4}{|c|}{ - } & \multicolumn{4}{|c|}{ - - } \\
\hline Total & $43.97 \mathrm{a}$ & $55.68 \mathrm{~b}$ & $57.20 \mathrm{~b}$ & * & 54.07 & 51.27 & 50.66 & ns \\
\hline 1 cut & $44.25 b$ & $63.25 \mathrm{a}$ & & $*$ & 53.75 & 57.12 & 50.37 & ns \\
\hline 2 cut & $53.00 \mathrm{~b}$ & $55.75 \mathrm{ab}$ & $74.42 \mathrm{a}$ & * & 57.25 & 56.17 & 59.75 & ns \\
\hline 3 cut & $39.36 \mathrm{~b}$ & $56.72 \mathrm{a}$ & $53.58 \mathrm{a}$ & * & 52.19 & 49.28 & 48.19 & ns \\
\hline 4 cut & $48.50 \mathrm{ab}$ & $44.91 \mathrm{~b}$ & $60.83 a$ & * & 56.75 & 48.33 & 49.17 & ns \\
\hline \multicolumn{9}{|l|}{ 1991-1992 } \\
\hline Total & 31.25 & $33.28 \mathrm{a}$ & $19.79 \mathrm{~b}$ & * & $23.65 \mathrm{~b}$ & $31.59 \mathrm{a}$ & $32.53 \mathrm{a}$ & * \\
\hline $1 \mathrm{cut}$ & 38.58 & 36.50 & & ns & $28.37 \mathrm{~b}$ & $40.57 \mathrm{ab}$ & $43.69 \mathrm{a}$ & * \\
\hline 2 cut & $33.17 \mathrm{~b}$ & $45.67 \mathrm{a}$ & $30.50 \mathrm{~b}$ & $*$ & $31.94 \mathrm{~b}$ & $37.19 \mathrm{ab}$ & $40.19 \mathrm{a}$ & ns \\
\hline 3 cut & $23.04 \mathrm{a}$ & $23.72 \mathrm{a}$ & $13.17 \mathrm{~b}$ & $*$ & 17.37 & 20.09 & 22.17 & ns \\
\hline 4 cut & $21.96 \mathrm{a}$ & $18.30 \mathrm{a}$ & $10.33 b$ & $*$ & $11.21 \mathrm{~b}$ & $22.54 \mathrm{a}$ & $16.50 \mathrm{ab}$ & * \\
\hline \multicolumn{9}{|c|}{ Legume } \\
\hline & No & N30 & N60 & Sig & K0 & K50 & K 100 & Sig. \\
\hline 1989-1990 & \multicolumn{4}{|c|}{ - } & \multicolumn{4}{|c|}{ - } \\
\hline Total & $26.75 a$ & $12.61 \mathrm{~b}$ & $10.63 b$ & * & $12.95 \mathrm{~b}$ & $16.93 \mathrm{ab}$ & $21.54 \mathrm{a}$ & * \\
\hline lcut & $18.58 \mathrm{a}$ & $8.92 b$ & & * & 7.25 & 17.62 & $16.37 \mathrm{a}$ & ns \\
\hline 2 cut & $13.33 \mathrm{a}$ & $9.08 \mathrm{a}$ & $2.67 b$ & $*$ & 5.58 & 8.67 & 10.83 & ns \\
\hline 3 cut & $37.01 \mathrm{a}$ & $15.78 \mathrm{~b}$ & $15.81 \mathrm{~b}$ & * & 17.61 & 22.94 & 28.08 & ns \\
\hline 4 cut & $17.42 \mathrm{a}$ & $10.33 \mathrm{~b}$ & $3.08 \mathrm{c}$ & $*$ & $8.08 \mathrm{~b}$ & $6.67 \mathrm{~b}$ & $16.08 \mathrm{a}$ & * \\
\hline \multicolumn{9}{|l|}{ 1991-1992 } \\
\hline Total & $10.07 \mathrm{ab}$ & $12.36 \mathrm{~b}$ & $18.38 \mathrm{a}$ & $*$ & $9.69 \mathrm{~b}$ & $14.06 \mathrm{~b}$ & $19.63 a$ & * \\
\hline 1 cut & 16.12 & 14.21 & & ns & $9.25 \mathrm{~b}$ & $19.19 \mathrm{~b}$ & $20.06 a$ & * \\
\hline 2 cut & 10.56 & 11.03 & 12.58 & ns & 9.19 & 11.75 & 13.22 & ns \\
\hline 3 cut & $23.00 \mathrm{ab}$ & $13.00 \mathrm{~b}$ & $21.17 \mathrm{a}$ & $*$ & $14.33 \mathrm{~b}$ & $19.59 \mathrm{~b}$ & $29.79 \mathrm{a}$ & * \\
\hline 4 cut & $6.29 \mathrm{~b}$ & $10.27 b$ & $18.29 \mathrm{a}$ & * & $6.37 \mathrm{~b}$ & $10.00 \mathrm{~b}$ & $18.50 \mathrm{a}$ & * \\
\hline \multicolumn{9}{|c|}{ Others } \\
\hline & No & N30 & N60 & Sig & K0 & K50 & $\mathrm{K} 100$ & Sig. \\
\hline 1989-1990 & \multicolumn{4}{|c|}{ - } & \multicolumn{4}{|c|}{ - } \\
\hline Total & 29.35 & 31.75 & 32.23 & ns & 33.44 & 31.87 & 27.82 & * \\
\hline 1 cut & $37.17 \mathrm{a}$ & $27.83 b$ & & $*$ & $39.00 \mathrm{a}$ & $25.25 \mathrm{ab}$ & $33.25 \mathrm{~b}$ & * \\
\hline 2 cut & 33.66 & 35.17 & 33.17 & ns & 37.17 & 35.25 & 29.58 & ns \\
\hline 3 cut & 23.58 & 27.56 & 30.67 & ns & 30.25 & 27.83 & 23.72 & ns \\
\hline $\begin{array}{l}4 \text { cut } \\
1991-1992\end{array}$ & 34.50 & 44.83 & 36.00 & ns & 35.58 & 34.75 & 45.00 & ns \\
\hline Total & 54.89 & 54.36 & 61.95 & ns & $66.67 \mathrm{a}$ & $54.36 \mathrm{~b}$ & $48.15 b$ & * \\
\hline 1 cut & 45.75 & 49.33 & & ns & $62.31 \mathrm{a}$ & $43.31 \mathrm{~b}$ & $37.00 \mathrm{~b}$ & * \\
\hline 2 cut & $56.27 \mathrm{a}$ & $43.39 \mathrm{~b}$ & $56.94 \mathrm{a}$ & $*$ & 58.83 & 51.03 & 46.75 & ns \\
\hline 3 cut & 54.21 & 63.18 & 59.92 & ns & $68.37 \mathrm{a}$ & $61.41 \mathrm{a}$ & $48.29 b$ & * \\
\hline 4 cut & 71.79 & 71.34 & 71.50 & ns & $82.54 a$ & $67.46 \mathrm{~b}$ & $64.96 \mathrm{~b}$ & * \\
\hline
\end{tabular}

Table 5. Response to nitrogen and potash fertilization (kg dry matter per $\mathrm{kg}$ of fertilizer applied).

\begin{tabular}{|c|c|c|c|c|c|c|}
\hline \multirow[b]{4}{*}{ Year } & \multicolumn{4}{|c|}{ Potash response } & \multicolumn{2}{|c|}{ Nitrogen response } \\
\hline & $N=0$ & $\mathrm{~N}=30$ & $N=60$ & $\mathrm{~K}=0$ & $\mathrm{~K}=100$ & $K=200$ \\
\hline & \multirow{2}{*}{\multicolumn{3}{|c|}{ From 0 to $100 \mathrm{~kg} \mathrm{~K}_{2} \mathrm{O}$}} & \multicolumn{3}{|c|}{ From 0 to $30 \mathrm{~kg} \mathrm{~N}$} \\
\hline & & & & 224 & & 113 \\
\hline $\begin{array}{l}1989 \\
1990\end{array}$ & $\begin{array}{r}8.2 \\
15.1\end{array}$ & $\begin{array}{r}2.3 \\
10.9\end{array}$ & $\begin{array}{r}-5.8 \\
0.3\end{array}$ & $\begin{array}{l}22.4 \\
19.0\end{array}$ & $\begin{array}{l}16.5 \\
12.0\end{array}$ & $\begin{array}{l}11.3 \\
-7.7\end{array}$ \\
\hline 1991 & 23.3 & 18.2 & 13.0 & 8.8 & 0.3 & -7.0 \\
\hline \multirow[t]{2}{*}{1992} & 8.9 & 13.8 & 13.3 & -5.5 & 2.7 & 6.0 \\
\hline & \multicolumn{3}{|c|}{ From 0 to $200 \mathrm{~kg} \mathrm{~K}_{2} \mathrm{O}$} & \multicolumn{3}{|c|}{ From 0 to $60 \mathrm{~kg} \mathrm{~N}$} \\
\hline 1989 & 5.4 & 0.1 & 7.9 & 15.2 & 3.5 & 19.4 \\
\hline 1990 & 11.0 & 3.0 & 4.5 & 15.5 & 3.2 & 4.7 \\
\hline 1991 & 20.2 & 15.4 & 7.7 & 14.8 & 6.2 & -6.0 \\
\hline 1992 & 7.9 & 11.3 & 10.8 & 6.4 & 10.1 & 11.2 \\
\hline
\end{tabular}

positive effect on protein production (for the silage cut) in the second and third harvest in 1989 and in 1990 , although this situation was reversed in the same cuttings for the following years. This might be due to the fact that in spite of a higher production in plots with higher doses of $\mathrm{N}$ the content of clover was higher in those with lower $\mathrm{N}$ doses. No effect was recorded in the autumn. Potassium content in the sward was not affected by $\mathrm{N}$ fertilization in most cuts, and no clear effect of $\mathrm{N}$ application on potassium content in pasture was found.

\section{Potassium Fertilization effects}

Potassium fertilization increased pasture DM production in most harvests, as shown in Fig. 1. This effect was clear after the second experiment year. Differences in accumulated pasture production rose from $5 \%$, by use of no potassium doses, to $30 \%$, using high $\mathrm{K}$ rates, respectively. The application of $200 \mathrm{~kg} \mathrm{~K}_{2} \mathrm{O}$ ha $^{-1}$ meant 2 or 3 tonnes of grass dry matter more than no $\mathrm{K}$ fertilization. Dry matter (DM) production response per $\mathrm{kg}$ of $\mathrm{K}_{2} \mathrm{O}$ applied was reduced when $\mathrm{N}$ doses increased (Table 4). This response raised from the first to the third year until $23 \mathrm{~kg}$ DM kg-1 of $\mathrm{K}_{2} \mathrm{O}$ applied. On the other hand, pasture production increase was higher when this fertilization rose from 0 to $100 \mathrm{~kg} \mathrm{~K}_{2} \mathrm{O} \mathrm{ha}{ }^{-1}$ than when the increment was from 100 to $200 \mathrm{~kg} \mathrm{~K}$ O $\mathrm{ha}^{-1}$, because in the first case, the limit effect was more important.

\section{Botanical composition}

Clover content in pasture was greater in plots with higher $\mathrm{K}$ rates. Higher $\mathrm{K}$ fertilization meant $50 \%$ more clover than no $\mathrm{K}$ application, reaching, in some cases $85 \%$, and the response between treatments increased from 1989 to 1992.

Potassium effects on the proportion of sown and spontaneous species are shown in Table 5. The fertilization with potassium did not affect the percentage of Lolium perenne in pasture in the 1989-1990 period. However, the application of this element improved the rye-grass proportion in pasture in 1991-1992. The clover content of pasture was always increased by $\mathrm{K}$ fertilization (Fig. .2). No clear effect of fertilization with this nutrient on the percentage of other species in pasture was found in the 1989-1990 period. However, K fertilization reduced such rate in 1991-1992 significantly. 

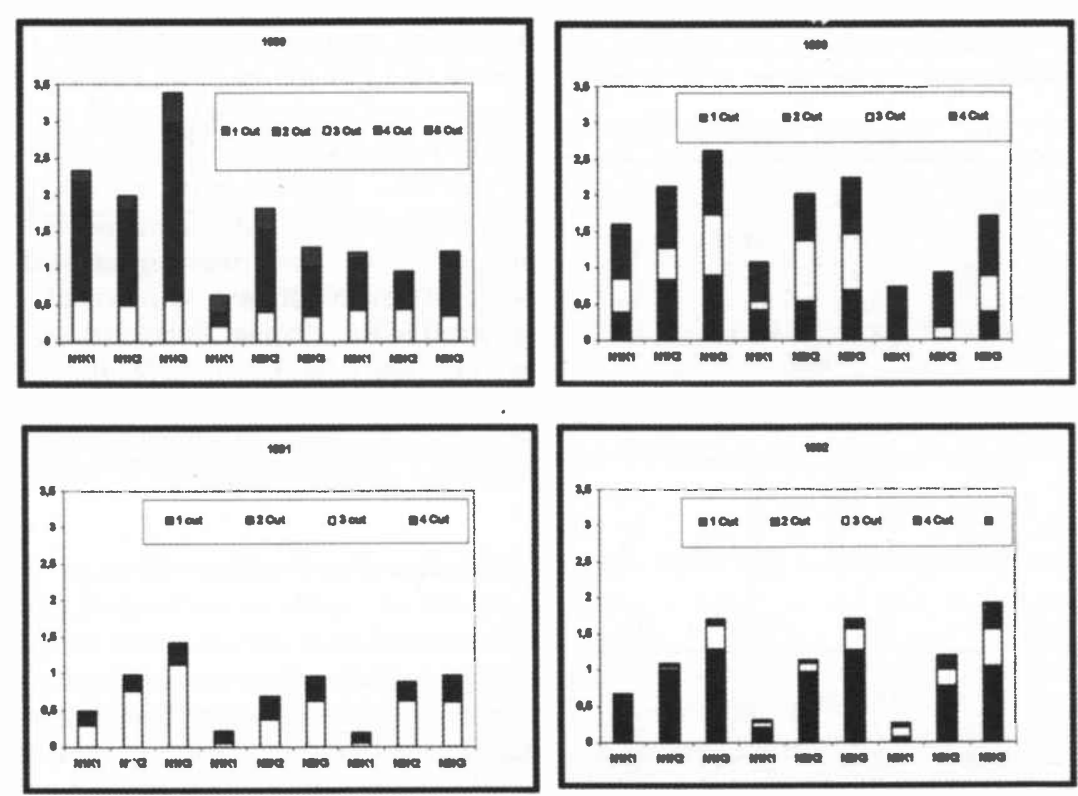

Fig. 2. Clover production (t/ha) under different treatments at different cutting dates in 1989 , 1990, 1991, and $1992 \mathrm{N1:} 0 \mathrm{~kg} \mathrm{~N} \mathrm{ha}^{-1}$; N2: $60 \mathrm{~kg} \mathrm{~N} \mathrm{ha}^{-1}(30+30) ; \mathrm{N3}: 120 \mathrm{~kg} \mathrm{~N} \mathrm{ha}^{-1}(60+$ 60); K1: $0 \mathrm{~kg} \mathrm{~K}_{2} \mathrm{O} \mathrm{ha}{ }^{-1}$; K2: $100 \mathrm{~kg} \mathrm{~K}_{2} \mathrm{O} \mathrm{ha}{ }^{-1}(50+50)$ and K3: $200 \mathrm{~kg} \mathrm{~K}_{2} \mathrm{O} \mathrm{ha}{ }^{-1}(100+$ 100)).

\section{Macro-element and micro-element contents}

Potassium fertilization did not affect $P$ (Table 8), Ca (Table 9) $\mathrm{Mg}$ (Table 10), $\mathrm{Zn}$ (Table 11) and $\mathrm{Cu}$ (Table 12) contents of pasture in any harvest. The application of $\mathrm{K}$ increased protein content of pasture in the first cutting, and $\mathrm{Mn}$ content in the second cutting, in 1991-1992 period, but reduced $\mathrm{Fe}$ content in the second cutting of the same period. The $\mathrm{K}$ content of pasture was increased by fertilizer $\mathrm{K}$ application in most harvests.

\section{Protein and potassium output}

Plots in which higher $\mathrm{K}_{2} \mathrm{O}$ rates were applied produced significantly more protein in the first cutting of the last 3 years. The content of $\mathrm{K}$ in pasture was significantly affected in first cuttings, by $\mathrm{K}_{2} \mathrm{O}$ fertilization, and $\mathrm{K}$ production was increased in the first cuttings of the last 3 years (Table 5).

\section{Relationships between element content of pasture}

The significant relationships between $P$, $\mathrm{Mg}, \mathrm{Fe}$, and $\mathrm{Cu}$ contents with $\mathrm{K}$ and protein proportion of pasture are shown in Figure 3. There were positive relationships between protein, $P$ and $K$ levels in pasture for the overall period $\left(r^{2}=0.76\right)$, spring overall $\left(r^{2}=0.88\right)$, and the first $\left(r^{2}=\right.$ $0.99)$ and last $\left(r^{2}=0.66\right)$ cuts of spring.
Table 6. Crude protein content $(\%)$ of pasture in each potsh or nitrogen treatment in the 2 period studied (1989-1990 and 1991-1992).

\begin{tabular}{|c|c|c|c|c|c|c|c|c|}
\hline & \multicolumn{3}{|c|}{ Nitrogen } & \multicolumn{5}{|c|}{ Potash } \\
\hline & No & N30 & N60 & Sig & K0 & K50 & $\mathrm{K} 100$ & Sig \\
\hline $1989-1990$ & \multicolumn{3}{|c|}{ - } & & \multicolumn{4}{|c|}{ (\%)-1...-- } \\
\hline Total & $14.14 \mathrm{a}$ & $14.02 \mathrm{a}$ & $12.90 \mathrm{~b}$ & $* * *$ & 13.92 & 13.50 & 13.81 & ns \\
\hline 1 cut & 16.41 & 16.35 & ns & 15.98 & 16.56 & 16.61 & ns & \\
\hline 2 cut & 14.23 & 13.07 & 13.59 & ns & 14.77 & 12.76 & 13.38 & ns \\
\hline 3 cut & 11.22 & 11.10 & 10.09 & ns & 10.69 & 10.76 & 10.91 & ns \\
\hline 4 cut & 15.44 & 15.45 & 14.65 & ns & 14.86 & 14.98 & 15.40 & ns \\
\hline \multicolumn{9}{|l|}{$1991-1992$} \\
\hline Total & $12.45 \mathrm{a}$ & $11.98 \mathrm{ab}$ & $11.06 \mathrm{~b}$ & * & 11.40 & 12.12 & 11.92 & ns \\
\hline 1 cut & 14.91 & 13.68 & ns & 12.34 & 13.04 & 12.88 & ns & \\
\hline 2 cut & 9.72 & 9.22 & 8.64 & ns & 8.67 & 10.06 & 8.86 & ns \\
\hline 3 cut & 11.01 & 10.61 & 11.44 & ns & 11.03 & 11.30 & 10.79 & ns \\
\hline 4 cut & $14.29 \mathrm{~b}$ & $14.83 b$ & $15.69 \mathrm{a}$ & * & $14.29 \mathrm{~b}$ & $14.52 \mathrm{~b}$ & $16.01 \mathrm{a}$ & $*$ \\
\hline
\end{tabular}

***P $<0.001 ; *: \mathrm{P}<0.05 ;$ ns: not significant.

Table 7. Phosphorus content $(\%)$ of pasture in each potash or nitrogen treatment in the 2 period studied (1989-1990 and 1991-1992).

\begin{tabular}{|c|c|c|c|c|c|c|c|c|}
\hline & \multicolumn{3}{|c|}{ Nitrogen } & \multicolumn{5}{|c|}{ Potash } \\
\hline & No & N30 & N60 & Sig. & Ko & K50 & $\mathrm{K} 100$ & Sig. \\
\hline 1989-1990 & \multicolumn{3}{|c|}{-....-- } & & \multicolumn{4}{|c|}{ - } \\
\hline Total & $0.35 \mathrm{a}$ & $0.35 \mathrm{a}$ & $0.33 b$ & $* *$ & 0.35 & 0.34 & 0.34 & ns \\
\hline 1 cut & 0.39 & 0.38 & & ns & 0.39 & 0.39 & 0.38 & ns \\
\hline 2 cut & $0.36 \mathrm{a}$ & $0.36 a$ & $0.33 b$ & $* * *$ & 0.36 & 0.34 & 0.34 & ns \\
\hline 3 cut & 0.32 & 0.32 & 0.31 & ns & 0.32 & 0.32 & 0.31 & ns \\
\hline 4 cut & 0.35 & 0.36 & 0.34 & ns & 0.36 & 0.34 & 0.34 & ns \\
\hline \multicolumn{9}{|l|}{ 1991-1992 } \\
\hline Total & $0.35 \mathrm{a}$ & $0.33 \mathrm{ab}$ & $0.31 b$ & $*$ & 0.34 & 0.34 & 0.32 & ns \\
\hline 1 cut & $0.40 \mathrm{a}$ & $0.38 \mathrm{a}$ & $0.30 \mathrm{~b}$ & * & 0.36 & 0.36 & 0.34 & ns \\
\hline 2 cut & 0.27 & 0.26 & 0.25 & ns & 0.26 & 0.28 & 0.25 & ns \\
\hline 3 cut & $0.39 a$ & $0.35 \mathrm{~b}$ & $0.37 a b$ & $*$ & 0.39 & 0.37 & 0.36 & ns \\
\hline 4 cut & 0.34 & 0.34 & 0.36 & ns & 0.35 & 0.35 & 0.34 & ns \\
\hline
\end{tabular}

${ }^{* * * \mathrm{P}}<0.001 ;{ }^{* * \mathrm{P}}<0.01 ;{ }^{*} \mathrm{P}<0.05$; ns: not significant.
Magnesium was negatively related to crude protein or $\mathrm{K}$ of pasture overall period $\left(r^{2}=0.58\right)$ and in the last cutting of spring $\left(\mathrm{r}^{2}=0.80\right)$. The $\mathrm{K}$ and protein contents of pasture were positively related to $\mathrm{Fe}$ in the overall period $\left(\mathrm{r}^{2}=0.64\right)$, and in the spring $\left(r^{2}=0.62\right)$, and to copper $\left(r^{2}=\right.$ 0.88 ) in the first cutting of spring.

The relationships between the macroelements of pasture are shown in Figure 4. A negative and significant relationship was found between $\mathrm{Mg}$ and protein in the overall period $\left(r^{2}=0.55\right)$, and in the last cut of spring $\left(r^{2}=0.62\right)$, and between $K$ and $\mathrm{Mg}\left(\mathrm{r}^{2}=0.74\right)$ in the spring. A positive relationship between $\mathrm{Ca}$ and $\mathrm{Mg}$ content was found in the overall period $\left(r^{2}\right.$ $=0.71$ ).

The relationships between macroelements and micro-elements are shown in Figure 5. The $\mathrm{Cu}$ content of pasture was related to all the macro-elements. These relationships were positive with $\mathrm{P}\left(\mathrm{r}^{2}=\right.$ $0.80)$, protein $\left(r^{2}=0.69\right)$, and $\mathrm{Ca}\left(r^{2}=\right.$ $0.77)$ in the first cutting, and $\mathrm{Mg}\left(\mathrm{r}^{2}=\right.$ 0.78 ) in the spring. However, the relationships between $\mathrm{Cu}$ and $\mathrm{Mg}$ and $\mathrm{Cu}$ 

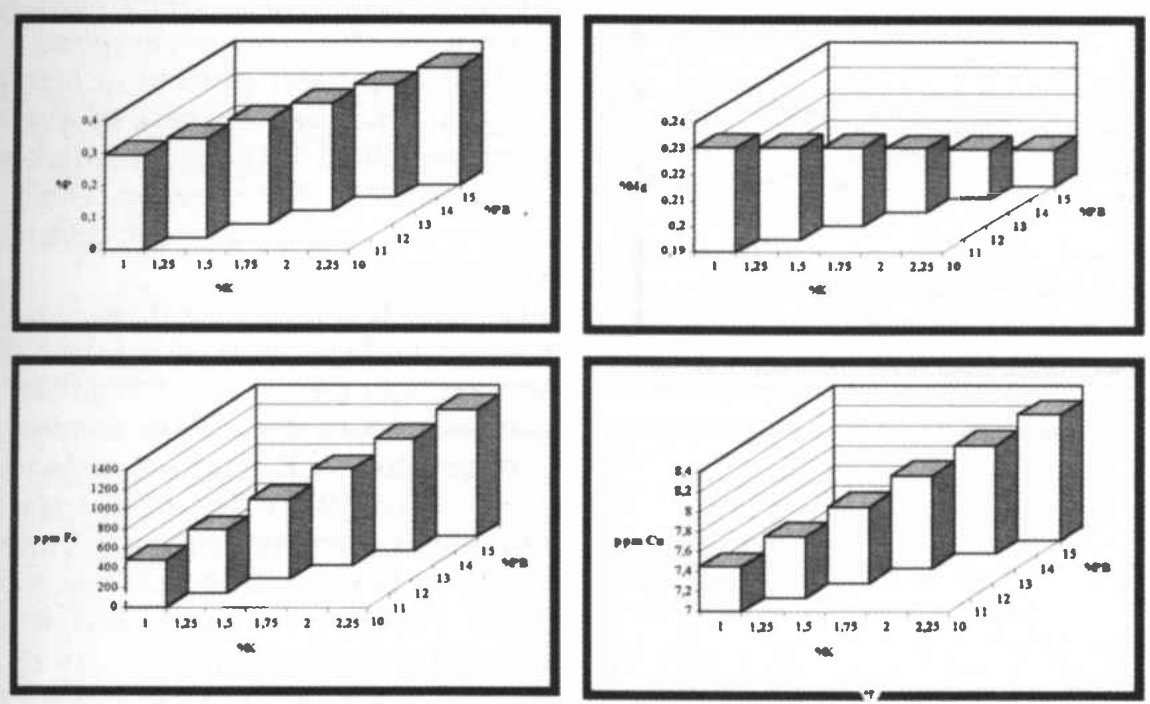

Fig. 3. Relationships between $\mathrm{P}, \mathrm{Mg}$, $\mathrm{Fe}$, and $\mathrm{Cu}$ concentrations with $\mathrm{K}$ and protein proportion of pasture.

and $\mathrm{Ca}$ were negative when the content of $\mathrm{Mg}$ and $\mathrm{Ca}$ were above 0.21 and 0.85 $\mathrm{ppm}$, respectively. Zinc was positively related to $\mathrm{Mg}$ in the second cutting $\left(\mathrm{r}^{2}=\right.$ 0.74 ) and negatively to $\mathrm{Ca}$ in the first cutting $\left(r^{2}=0.81\right)$. Manganese was negatively related with $\mathrm{Ca}$ in autumn $\left(\mathrm{r}^{2}=\right.$ 0.53 ).

\section{Discussion}

Pasture production increased with application of $\mathrm{N}$ with the exception of the second year, when $\mathrm{N}$ application was associated with decreased Trifolium content. Cold temperatures retard the growth of Trifolium repens at the beginning of the growing season, which causes a low $\mathrm{N}$ status in soil, unless $\mathrm{N}$ fertilizer is applied (Davies 1989). In 1990 , the mean temperatures for the 3 first months of the year were $1.44,2.13$, and 3.6 C higher than in 1989,1991 , and 1992, respectively. This favoured fast development of Trifolium, leading to more $\mathrm{N}$ in soils where $\mathrm{N}$ fertilizer was withheld in 1990 than in 1991 and 1992. Berthelsen et al. (1994) found similar changes in soil $\mathrm{N}$ associated with Trifolium repens in the sward. The appearance of Trifolium in the sward was delayed in the establishment year. In $1990,30 \mathrm{~kg} \mathrm{~N}$ ha $^{-1}$ were introduced by Trifolium in $0 \mathrm{~N}$ plots (Fig. 1) and no response when $30 \mathrm{~kg} \mathrm{~N} \mathrm{ha}^{-1}$ fertilizer was applied.

Applying $30 \mathrm{~kg} \mathrm{~N} \mathrm{ha}^{-1}$ fertilizer increased annual pasture production in the first year, followed by a decline in the studied (1989-1990 and 1991-1992).

${ }^{* * *} \mathrm{P}<0.001 ; * \mathrm{P}<0.05$; ns: not significant. ied (1989-1990 and 1991-1992).

${ }^{*} \mathrm{P}<0.05$; ns: not significant. second and third years, and no response in the fourth year. The control $(0 \mathrm{~N})$ favoured an increase of clover content in the sward resulting in no differences or declines in annual pasture production relative to $\mathbf{N}$ application.

Fertilization with $\mathrm{K}$ increased pasture production and Trifolium content of the first harvest in the last 3 years of the experiment and agrees with observations reported by Simpson et al. (1988). The lack of response to $\mathrm{K}$ in the first harvest in 1989 can be explained by insufficient time for different species in the sward to adapt to $\mathrm{K}$ fertilization. Production increased at the second harvest where $\mathrm{K}$ was applied at the $0 \mathrm{~N}$ treatment and agrees with earlier findings reported by Mosquera et al. (1992). Nitrogen fertilization of silage cut, increased pasture production, as did $\mathrm{K}$ fertilization for the first and second cuttings, in all 4 years of study.

Nitrogen increased pasture DM production by the third cutting of the first

Table 8. Potassium content $(\%)$ of pasture in each potash or nitrogen treatment in the 2 period

\begin{tabular}{|c|c|c|c|c|c|c|c|c|}
\hline & \multicolumn{3}{|c|}{ Nitrogen } & \multicolumn{5}{|c|}{ Potash } \\
\hline & No & N30 & N60 & Sig & K0 & K50 & $\mathrm{K} 100$ & Sig \\
\hline 1989-1990 & \multicolumn{3}{|c|}{ - } & \multicolumn{5}{|c|}{ - } \\
\hline Total & $2.00 \mathrm{a}$ & $1.94 \mathrm{a}$ & $1.68 \mathrm{~b}$ & $*$ & $1.69 \mathrm{a}$ & $1.93 \mathrm{a}$ & $1.69 \mathrm{~b}$ & $*$ \\
\hline 1 cut & 2.52 & 2.48 & & ns & $1.88 \mathrm{c}$ & $2.64 \mathrm{~b}$ & $2.98 \mathrm{a}$ & $*$ \\
\hline 2 cut & $2.47 \mathrm{a}$ & $2.28 \mathrm{ab}$ & $2.17 \mathrm{~b}$ & $*$ & $2.15 b$ & $2.30 \mathrm{ab}$ & $2.44 a$ & $*$ \\
\hline 3 cut & 1.60 & 1.64 & 1.48 & ns & $1.37 \mathrm{a}$ & $1.62 \mathrm{ab}$ & $1.74 b$ & $* *$ \\
\hline 4 cut & 1.68 & 1.54 & 1.36 & ns & 1.50 & 1.52 & 1.47 & ns \\
\hline \multicolumn{9}{|l|}{ 1991-1992 } \\
\hline Total & 1.76 & 1.82 & 1.70 & ns & $1.63 b$ & $1.69 \mathrm{ab}$ & $1.95 b$ & $*$ \\
\hline 1 cut & $1.85 \mathrm{a}$ & $1.73 a$ & $1.30 \mathrm{~b}$ & $*$ & $1.28 \mathrm{~b}$ & $1.56 \mathrm{~b}$ & $1.94 \mathrm{a}$ & $*$ \\
\hline 2 cut & 1.61 & 2.22 & 1.98 & ns & 1.99 & 1.81 & 2.01 & ns \\
\hline 3 cut & $1.28 \mathrm{a}$ & $1.30 \mathrm{a}$ & $1.06 \mathrm{~b}$ & ns & $1.23 \mathrm{ab}$ & $1.12 b$ & $1.30^{\circ}$ & $*$ \\
\hline 4 cut & 2.33 & 2.13 & 2.44 & ns & $2.07 \mathrm{~b}$ & $2.30 \mathrm{ab}$ & $2.53^{\circ}$ & $*$ \\
\hline
\end{tabular}

Table 9. Calcium content $(\%)$ of pasture in each potash or nitrogen treatment in the 2 period stud-

\begin{tabular}{|c|c|c|c|c|c|c|c|c|}
\hline & \multicolumn{3}{|c|}{ Nitrogen } & \multicolumn{5}{|c|}{ Potash } \\
\hline & No & N30 & N60 & Sig & K0 & K50 & $\mathrm{K} 100$ & Sig \\
\hline $1989-1990$ & \multicolumn{4}{|c|}{ - } & \multicolumn{4}{|c|}{ 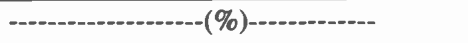 } \\
\hline Total & $0.87 \mathrm{a}$ & $0.83 \mathrm{ab}$ & $0.78 b$ & * & 0.85 & 0.82 & 0.83 & ns \\
\hline 1 cut & $0.98 \mathrm{a}$ & $0.85 b$ & & * & 0.89 & 0.91 & 0.94 & ns \\
\hline 2 cut & 0.68 & 0.72 & 0.63 & ns & 0.73 & 0.65 & 0.65 & ns \\
\hline 3 cut & $0.86 a$ & $0.76 \mathrm{ab}$ & $0.75 b$ & $*$ & 0.80 & 0.75 & 0.83 & ns \\
\hline 4 cut & $0.77 b$ & $0.82 b$ & $0.97 \mathrm{a}$ & $*$ & 0.92 & 0.87 & 0.86 & ns \\
\hline \multicolumn{9}{|l|}{ 1991-1992 } \\
\hline Total & 1.16 & 1.26 & 1.27 & ns & 1.23 & 1.24 & 1.23 & ns \\
\hline 1 cut & 0.75 & 0.72 & 0.81 & ns & 0.81 & 0.75 & 0.73 & ns \\
\hline 2 cut & 1.08 & 1.18 & 1.22 & ns & 1.10 & 1.17 & 1.20 & ns \\
\hline 3 cut & 1.69 & 2.08 & 1.97 & ns & 1.91 & 1.99 & 1.83 & ns \\
\hline 4 cut & 1.37 & 1.46 & 1.52 & ns & 1.45 & 1.43 & 1.48 & ns \\
\hline
\end{tabular}



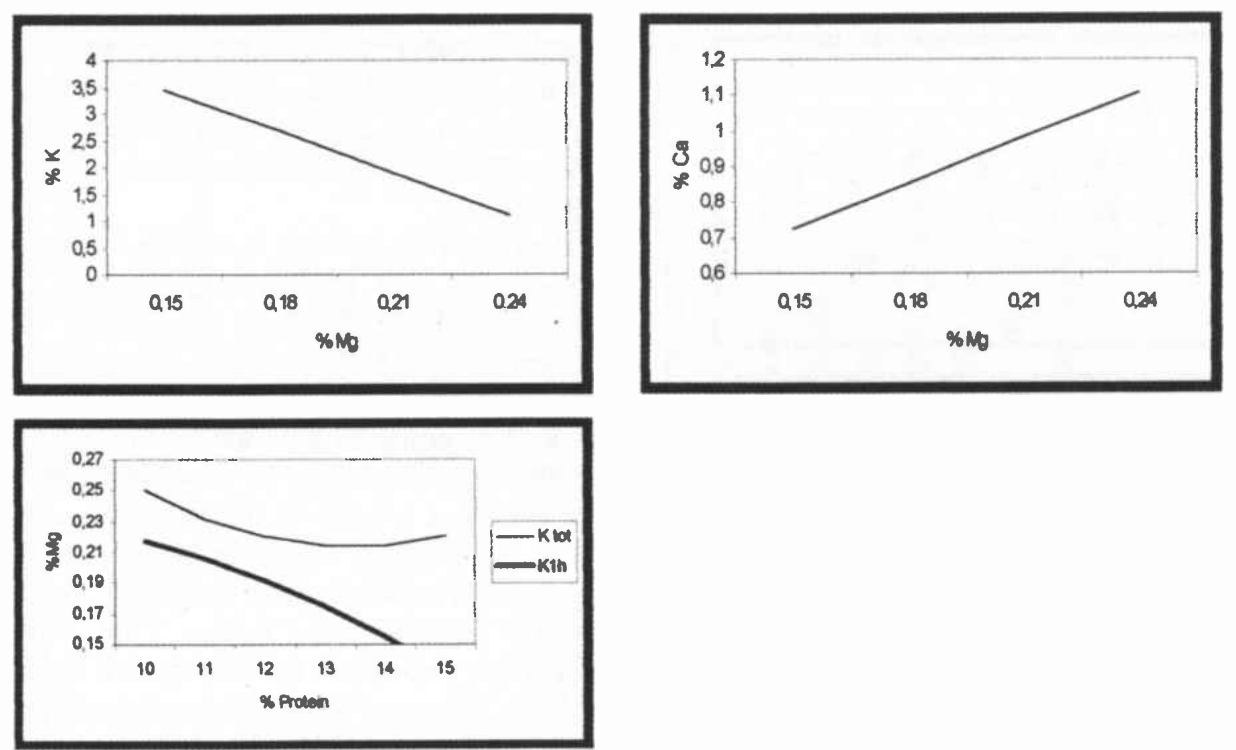

Fig. 4. Relationships between the maco-elements of pasture.

year, but decreased DM production in the second and third years, with no response observed for the last year. Trifolium content decreased with $\mathrm{N}$ and increased with $\mathrm{K}$ and corresponds to observations reported by Chapman et al. (1996), and Clark and Harris (1996). High temperatures and rainfall stimulated clover development, which led to $\mathrm{N}$ accumulation in the soil. On the other hand, $\mathrm{K}$ fertilization increased resistance to water stress, as found by Robin et al. (1989). This caused an interaction between $\mathrm{K}$ and $\mathrm{N}$ fertilization.

Nitrogen fertilization significantly increased annual total and spring production in 1989. However, K fertilization increased DM yield in all years, with the exception of 1989 . Comparing $\mathrm{N} 1 \mathrm{~K} 3$ and $\mathrm{N} 3 \mathrm{~K} 3$ treatments showed that $\mathrm{N}$ could substitute for $\mathrm{K}$ leading to similar amounts of herbage DM production This indicates that Trifolium is very dependent on $\mathrm{K}$ fertilization, even in soils with moderate amounts of $K$. Farmers question the value of Trifolium as a source of $\mathrm{N}$, because the presence and amount of clover in a sward is unpredictable as is the amount of $\mathrm{N}$ fixed by the legume in the sward. However, it is very important to note what happens to $K$ in the soil. Annual fertilization with $\mathrm{K}$ is very important when high rates of $\mathrm{N}$ are applied, as high pasture yield can deplete $\mathrm{K}$ from the soil with time, as suggested by Simpson et al. (1988).

Protein production increased as $\mathrm{N}$ fertilization increased, but only when $\mathrm{N}$ application increased pasture production, which compensated for the lower proportion of protein in the grass studied (1989-1990 and 1991-1992). ied (1989-1990 and 1991-1992). dominated swards (second cuttings of the first and second years). The situation changed as Trifolium increased as a fraction of the sward. Trifolium increased protein in herbage because of the inherently greater protein in legume (Norton 1982) and because of overall increased productivity (Meister and Lehmann 1985). These factors contribute to the overall increased protein content of swards fertilized with $\mathrm{K}$.

The high $\mathrm{K}$ content of herbage growing in soils with high levels of $K$ is normally due to a high proportion of Trifolium in such swards (Chevalier 1981). Trifolium is more sensitive to $\mathrm{K}$ fertilization than are grasses (Cox 1973). The persistence of leguminous plants in pasture is closely related to $\mathrm{K}$ fertilization (Floate et al. 1981). Pasture production efficiency attributed to fertilizer inputs was $16 \mathrm{~kg}$ of DM per $\mathrm{kg}$ of $\mathrm{K}$ and $15 \mathrm{~kg}$ of DM per $\mathrm{kg}$ of $\mathrm{N}$ (Simpson et al. 1988). In the present experiment, the values were 9.68 and 8.72 $\mathrm{kg}$ DM per $\mathrm{kg}$ nutrient, respectively. This could be explained because $\mathrm{K}$ content in the soil, was deficient and $\mathrm{N}$ was low in the experiment reported by Simpson et al. (1988).

Protein, $\mathrm{P}, \mathrm{K}$, and $\mathrm{Cu}$ levels in pasture

Table 10. Magnesium content $(\%)$ of pasture in each potash or nitrogen treatment in the 2 period

\begin{tabular}{|c|c|c|c|c|c|c|c|c|}
\hline & \multicolumn{3}{|c|}{ Nitrogen } & \multicolumn{5}{|c|}{ Potash } \\
\hline & No & N30 & N60 & Sig & K0 & K50 & K100 & Sig \\
\hline $1989-1990$ & \multicolumn{4}{|c|}{ - } & \multicolumn{4}{|c|}{ - } \\
\hline Total & 0.2 & 0.2 & 0.2 & ns & 0.2 & 0.2 & 0.2 & ns \\
\hline 1 cut & 0.2 & 0.2 & & ns & 0.21 & 0.2 & 0.2 & ns \\
\hline 2 cut & 0.17 & 0.18 & 0.17 & ns & 0.18 & 0.17 & 0.17 & ns \\
\hline 3 cut & 0.19 & 0.18 & 0.18 & ns & 0.18 & 0.18 & 0.18 & ns \\
\hline 4 cut & $0.27 \mathrm{a}$ & $0.28 \mathrm{a}$ & $0.25 b$ & $* * *$ & 0.27 & 0.26 & 0.27 & ns \\
\hline \multicolumn{9}{|l|}{$1991-1992$} \\
\hline Total & 0.22 & 0.22 & 0.24 & ns & 0.23 & 0.23 & 0.22 & ns \\
\hline 1 cut & $0.18 \mathrm{ab}$ & $0.17 b$ & $0.20^{\circ}$ & $*$ & 0.19 & 0.18 & 0.17 & ns \\
\hline 2 cut & 0.21 & 0.22 & 0.22 & ns & 0.22 & 0.22 & 0.21 & ns \\
\hline $3 \mathrm{cut}$ & $0.25 b$ & $0.27 \mathrm{ab}$ & $0.28 \mathrm{a}$ & $*$ & 0.25 & 0.27 & 0.27 & ns \\
\hline 4 cut & 0.26 & 0.28 & 0.29 & ns & 0.27 & 0.27 & 0.28 & ns \\
\hline
\end{tabular}

Table 11. Zinc content (ppm) of pasture in each potash or nitrogen treatment in the $\mathbf{2}$ period stud-

\begin{tabular}{|c|c|c|c|c|c|c|c|c|}
\hline & \multicolumn{3}{|c|}{ Nitrogen } & \multicolumn{5}{|c|}{ Potash } \\
\hline & No & N30 & N60 & Sig & K0 & K50 & $\mathrm{K} 100$ & Sig \\
\hline $1989-1990$ & \multicolumn{4}{|c|}{ 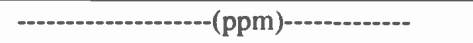 } & \multicolumn{4}{|c|}{ 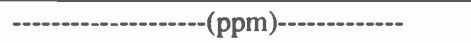 } \\
\hline Total & 26.51 & 26.84 & 26.16 & ns & 26.49 & 26.43 & 26.68 & ns \\
\hline 1 cut & 30.36 & 29.58 & & ns & 29.72 & 29.76 & 30.41 & ns \\
\hline 2 cut & $22.60 \mathrm{~b}$ & $22.12 b$ & $26.93 a$ & $*$ & 23.51 & 24.64 & 23.50 & ns \\
\hline 3 cut & $24.52 \mathrm{ab}$ & $25.97 \mathrm{a}$ & $23.08 b$ & * & 24.70 & 24.09 & 24.78 & ns \\
\hline 4 cut & 28.58 & 30.35 & 29.68 & ns & 29.58 & 29.51 & 29.58 & ns \\
\hline \multicolumn{9}{|l|}{ 1991-1992 } \\
\hline Total & 26.38 & 26.64 & 28.17 & ns & 27.14 & 27.98 & 26.17 & ns \\
\hline 1 cut & 22.49 & 22.40 & & ns & 23.19 & 24.01 & 23.05 & ns \\
\hline 2 cut & 25.17 & 24.51 & 26.34 & ns & 24.88 & 26.21 & 24.93 & ns \\
\hline 3 cut & 26.14 & 25.71 & 26.23 & ns & 26.05 & 26.54 & 25.56 & $\mathrm{~ns}$ \\
\hline 4 cut & 34.29 & 37.04 & 39.11 & ns & 38.20 & 38.39 & 33.85 & ns \\
\hline
\end{tabular}

*P $<0.05$; ns: not significant. 

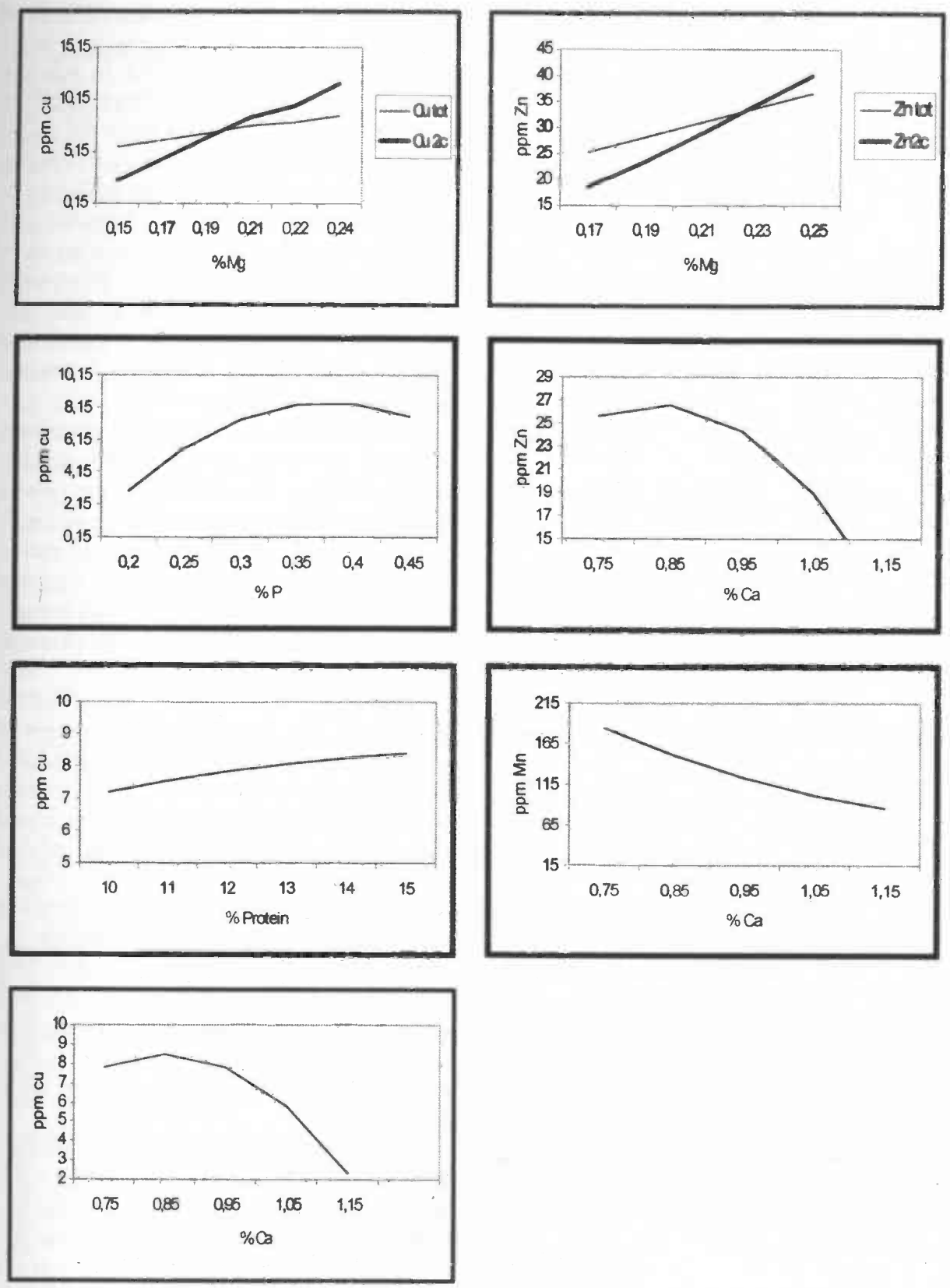

Fig. 5. Relationships between macro-elements and micro-elements of pasture.

herbage were lower in the last spring harvest because of development stage. Calcium, $\mathrm{Mn}, \mathrm{Fe}$, and $\mathrm{Mg}$ content increased, as described by Reid and Horvath (1980), Metson and Saunders (1978), Hopkins et al. (1994), and Mosquera et al. (1999).

Normal levels of protein and $\mathrm{P}$ in the area were found and $\mathrm{K}$ content was higher than those found in amphibole-derived soils, as in our research the schist-derived soil had higher K content (Mosquera et al. 1999). Nitrogenous fertilization had a negative effect on protein, $\mathrm{P}$ and $\mathrm{K}$ content of soil, mainly due to the higher clover proportion in unfertilized plots, in relation to other species (Mosquera and González 1997).
Whitehead (1995) found that $\mathrm{N}$ application reduced $\mathrm{K}$ concentration where unfertilised plots had less than $2 \%$ K. In the present experiment, $N$ fertilization decreased $K$ content of pasture herbage, but this varied with soil $\mathrm{K}$ (see Hopkins et al. 1994). The $\mathrm{N}$ rates applied in the present experiment were significantly lower than the levels used in the experiments of Hopkins et al. (1994) and Whitehead (1995). However, in the present experiments, clover content was higher in the lower $\mathrm{N}$ treatments, which increased the $K$ content of pasture, associated with greater Trifolium content in the sward (Chevalier 1981).
Calcium, in 1989-1990, was in a range (0.70-0.95\%) considered normal for pastures in temperate regions (Grace 1983a). In 1991-1992, Ca concentration in available herbage increased because the forb content of the sward was higher. In 1991-1992, differences in the percentage of Trifolium in swards receiving different amounts of $\mathrm{N}$ were less than in 1989-1990, and percentages of other species rose from $31 \%$ in $1989-1990$ to $71 \%$ in 1991-1992. The other species usually had higher levels of $\mathrm{Ca}$ than the sown species.

Hopkins et al. (1994) and Babnik et al. (1996) found that $\mathrm{N}$ fertilization reduced the $\mathrm{Ca}$ content of pasture, as we found in the first year. This could be explained by the higher legume content in non-fertilised plots that had higher $\mathrm{Ca}$ contents than did Lolium (Whitehead 1995). Magnesium content was generally below a critical value of $0.2 \%$, which may cause osteomalacia in lactating cattle. The critical value was reached and exceeded in 1991-1992, as forbs increased as a proportion of pasture.

The response of $\mathrm{Mg}$ in herbage to $\mathrm{N}$ is not clear. Hopkins et al. (1994) found that $\mathrm{N}$ fertilization reduced $\mathrm{Mg}$ content, whereas Simpson et al. (1988) observed an increase. In the present experiment, differences were detected between treatments when $\mathrm{Mg}$ concentration and clover content was higher (last cutting of the year).

The critical values of different macroelements in feed suggested as meeting the needs of livestock were always reached (NRC 2001, ARC 1991, Grace 1983a, 1983b, 1983c). In this experiment mean values were crude protein (7.3-11.2\%), phosphorus $(0.3-0.4 \%)$, potassium $(0.8 \%)$, calcium $(0.5 \%)$ and zinc (20-50 ppm). Copper and $\mathrm{Mg}$ content were below the critical values for milking cows: $12 \mathrm{ppm}$ and $0.2 \%$, respectively (Loué 1988, Hopkins et al. 1994).

Copper content was in the 6 to $12 \mathrm{ppm}$ range, which was adequate for plant nutrition (Kabata and Pendías 1984), and was not significantly different between treatments in spite of differences in botanical composition of the swards (Babnik et al. 1996). Whitehead (1995) noted the mixed effects of $\mathrm{N}$ fertilization on $\mathrm{Cu}$ content of pasture, when $\mathrm{N}$ source influenced soil $\mathrm{pH}$ affecting bioavailability of mineral nutrients from soil.

Iron concentrations in soil were between 300 and $2200 \mathrm{ppm}$, which meet plant needs (50-250 ppm) for growth (Kabata and Pendías 1984). Generally, $\mathrm{N}$ fertilization did 
Table 12. Copper content (ppm) of pasture in each potash or nitrogen treatment in the 2 period studied (1989-1990 and 1991-1992).

\begin{tabular}{|c|c|c|c|c|c|c|c|c|}
\hline & \multicolumn{3}{|c|}{ Nitrogen } & \multicolumn{5}{|c|}{ Potash } \\
\hline & No & N30 & N60 & Sig & K0 & K50 & $\mathrm{K} 100$ & Sig. \\
\hline $1989-1990$ & \multicolumn{4}{|c|}{ 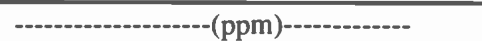 } & \multicolumn{4}{|c|}{ 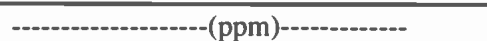 } \\
\hline Total & 7.55 & 7.73 & 7.53 & ns & 7.69 & 7.61 & 7.54 & ns \\
\hline 1 cut & 8.70 & 8.94 & & ns & 8.60 & 8.98 & 8.62 & ns \\
\hline 2 cut & $6.71 \mathrm{a}$ & $6.85 \mathrm{a}$ & $8.23 b$ & ns & 7.61 & 7.14 & 7.05 & ns \\
\hline 3 cut & 6.60 & 6.81 & 6.38 & ns & 6.63 & 6.44 & 6.72 & ns \\
\hline 4 cut & 8.31 & 8.75 & 8.17 & ns & 7.94 & 8.81 & 8.38 & ns \\
\hline \multicolumn{9}{|l|}{ 1991-1992 } \\
\hline Total & 7.69 & 7.59 & 8.03 & ns & 7.88 & 7.99 & 7.47 & ns \\
\hline 1 cut & 8.40 & 7.65 & & ns & 8.07 & 7.56 & 7.62 & ns \\
\hline 2 cut & 5.70 & 6.01 & 6.77 & ns & 6.27 & 6.13 & 6.10 & ns \\
\hline 3 cut & 7.07 & 7.01 & 7.9 & ns & 6.98 & 8.12 & 6.98 & ns \\
\hline 4 cut & 10.24 & 10.26 & 11.39 & ns & 10.87 & 11.25 & 9.78 & ns \\
\hline
\end{tabular}

Table 13. Iron content (ppm) of pasture in each potash or nitrogen treatment in the 2 period studied (1989-1990 and 1991-1992).

\begin{tabular}{|c|c|c|c|c|c|c|c|c|}
\hline & \multicolumn{3}{|c|}{ Nitrogen } & \multicolumn{5}{|c|}{ Potash } \\
\hline & No & N30 & N60 & Sig & K0 & K50 & $\mathrm{K} 100$ & Sig. \\
\hline $1989-1990$ & \multicolumn{4}{|c|}{ - } & \multicolumn{4}{|c|}{ - } \\
\hline Total & 1321.6 & 336.7 & 310.4 & ns & 1325 & 380.4 & 357.6 & ns \\
\hline 1 cut & 390.6 & 407.4 & & ns & 419.65 & 433.46 & 343.99 & ns \\
\hline 2 cut & 314.24 & 369.62 & 347.11 & ns & 318.52 & 353.94 & 358.51 & ns \\
\hline 3 cut & 292 & 224 & 205 & ns & 2935 & 208 & 206 & ns \\
\hline 4 cut & 994 & 353 & 373 & ns & 434 & 638 & 562 & ns \\
\hline \multicolumn{9}{|l|}{ 1991-1992 } \\
\hline Total & 974 & 722 & 748 & ns & 895 & 778 & 763 & ns \\
\hline 1 cut & 1285 & 725 & 639 & ns & $1234 a$ & $690 \mathrm{~b}$ & $684 b$ & $* * *$ \\
\hline 2 cut & 319 & 255 & 322 & ns & 280 & 311 & 305 & ns \\
\hline 3 cut & 338 & 227 & 290 & ns & 279 & 293 & 325 & ns \\
\hline 4 cut & $2087 \mathrm{a}$ & $1403 b$ & $1257 \mathrm{c}$ & $* * *$ & 1397 & 1630 & 1598 & ns \\
\hline
\end{tabular}

***P $<0.001$; ns:not significant

Table 14. Manganese content (ppm) of pasture in each potash or nitrogen treatment in the two period studied (1989-1990 and 1991-1992).

\begin{tabular}{|c|c|c|c|c|c|c|c|c|}
\hline & \multicolumn{3}{|c|}{ Nitrogen } & \multicolumn{5}{|c|}{ Potash } \\
\hline & NO & N30 & N60 & Sig & K0 & K50 & $\mathrm{K} 100$ & Sig. \\
\hline $1989-1990$ & \multicolumn{4}{|c|}{ - } & \multicolumn{4}{|c|}{ 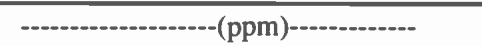 } \\
\hline Total & 63.53 & 61.76 & 60.28 & ns & 58.45 & 63.77 & 63.78 & ns \\
\hline $1 \mathrm{cut}$ & 55.63 & 54.21 & & ns & 49.32 & 55.66 & 59.79 & ns \\
\hline 2 cut & 81.99 & 73.10 & 70.29 & ns & 69.89 & 78.19 & 77.29 & ns \\
\hline 3 cut & 52.45 & 61.47 & 53.43 & ns & 54.88 & 57.27 & 55.21 & ns \\
\hline 4 cut & 67.86 & 53.98 & 53.36 & ns & 54.80 & 58.26 & 59.99 & ns \\
\hline \multicolumn{9}{|l|}{ 1991-1992 } \\
\hline Total & 103.81 & 96.92 & 94.91 & ns & 98.14 & 101.15 & 96.10 & ns \\
\hline $1 \mathrm{cut}$ & 114.81 & 103.93 & 94.17 & ns & 106.35 & 109.31 & 95.01 & ns \\
\hline 2 cut & $91.01 \mathrm{~b}$ & $91.64 b$ & $103.13 a$ & $*$ & $89.14 b$ & $102.36 \mathrm{a}$ & $94.27 \mathrm{ab}$ & $*$ \\
\hline 3 cut & 92.51 & 77.37 & 71.02 & ns & 80.26 & 79.56 & 81.27 & ns \\
\hline $4 \mathrm{cut}$ & 117.74 & 114.13 & 107.92 & ns & 115.82 & 108.45 & 115.52 & ns \\
\hline
\end{tabular}

*P $<0.05$; ns: not significant. not affect Fe content of pasture. Whitehead (1995) indicated that the effect of $\mathrm{N}$ fertilization on $\mathrm{Fe}$ content in pasture depended on $\mathrm{pH}$ effects of $\mathrm{N}$ fertilizer.

A critical value of $20 \mathrm{ppm}$ for $\mathrm{Zn}$ in available herbage was always exceeded in the present experiment. The effect of $\mathrm{N}$ fertilization on $\mathrm{Zn}$ content of pasture was not clear. Loué (1988) and Hopkins et al. (1994) attributed the negative effect of $\mathrm{N}$ fertilization on $\mathrm{Zn}$ content to dilution. However, Whitehead (1995) mentioned that no effect was detected if less than 300 $\mathrm{kg} \mathrm{N} \mathrm{ha}{ }^{-1}$ was applied.

Protein, $\mathrm{P}, \mathrm{K}$, and $\mathrm{Cu}$ were positively related as Monterroso (1995) found, mainly because these elements are present in high concentrations when pasture is freshly sown, and become less as the sward matures. However, $\mathrm{Ca}$ and $\mathrm{Mg}$ content was usually higher in mature leaves and flowers than in young plants as described by Willman et al. (1994).

Potassium fertilization did not affect the protein, $\mathrm{P}, \mathrm{Ca}, \mathrm{Mg}, \mathrm{Cu}$, or $\mathrm{Zn}$ content of pasture, in spite of differences in botanical composition caused by the different treatments. Simpson et al. (1988) indicated that protein content of clover was reduced with higher $\mathrm{K}$, describing also the absence of a response, regarding the protein content, of pasture with $\mathrm{K}$ fertilization. The effect of $\mathrm{K}$ on botanical composition was clear in 1991-1992, when a possible deficiency of $\mathrm{K}$ may have appeared in non-fertilised soil. In this interval, Lolium content of pasture was increased by $\mathrm{K}$ fertilization.

Potassium fertilization did not affect the $\mathrm{Mg}$ content of pasture, but overall there was a negative relationship between $\mathrm{Mg}$ content and $\mathrm{K}$. Fertilization with $\mathrm{K}$ usually reduced the $\mathrm{Mg}$ content of grass (Dampney 1992), but increased this element in clover (Simpson et al. 1988). Therefore, the negative effect of $\mathrm{K}$ fertilizer on $\mathrm{Mg}$ of some species can be compensated by the increase of Trifolium in the sward. On the other hand, lower $\mathrm{Mg}$ content occurred in 1989-1990 relative to 1991-1992, when proportion of forbs in the sward increased.

In Galicia, it is normal to apply $100 \mathrm{~kg}$ $\mathrm{K}_{2} \mathrm{O} \mathrm{ha}^{-1}$ and 30 or $40 \mathrm{~kg} \mathrm{~N} \mathrm{ha}^{-1}$ after each grazing. From our work, $\mathrm{K}_{2} \mathrm{O}$ applications should be increased unless managing the sward under cutting conditions. Increased $\mathrm{K}$ should lead to higher pasture and protein production and better forage quality through increased Trifolium and Lolium production and persistence. 
Table 15. Protein production (kg/ha) of sward in each cut, year and treatment.

\begin{tabular}{|c|c|c|c|c|c|c|c|c|}
\hline & $\mathbf{N}=0$ & $\mathrm{~N}=30$ & $\mathrm{~N}=60$ & Sig & $K=0$ & $K=50$ & $K=100$ & Sig. \\
\hline Year 1989 & \multicolumn{4}{|c|}{ - } & \multicolumn{4}{|c|}{ - } \\
\hline 1 cut & 630 & 820 & & $* * *$ & 690 & 760 & 710 & ns \\
\hline 2 cut & $220 \mathrm{~b}$ & $230 \mathrm{~b}$ & $890 \mathrm{a}$ & $* * *$ & 440 & 420 & 480 & ns \\
\hline 3 cut & $200 \mathrm{~b}$ & $380 a$ & $350 \mathrm{a}$ & $* * *$ & 300 & 300 & 320 & ns \\
\hline 4 cut & $360 a$ & $240 \mathrm{ab}$ & $190 \mathrm{~b}$ & $* * *$ & 250 & 230 & 310 & ns \\
\hline 5 cut & 250 & & 250 & & 270 & & ns & \\
\hline 240 & & & 250 & & 280 & & ns & \\
\hline \multicolumn{9}{|l|}{ Year 1990} \\
\hline 1 cut & 360 & 360 & & ns & $320 \mathrm{~b}$ & $370 \mathrm{ab}$ & $400 \mathrm{a}$ & $* * *$ \\
\hline 2 cut & $240 \mathrm{~b}$ & $250 \mathrm{~b}$ & $690 a$ & $* * *$ & 360 & 380 & 450 & ns \\
\hline 3 cut & $370 \mathrm{ab}$ & $440 \mathrm{a}$ & $310 \mathrm{~b}$ & $* *$ & 320 & 420 & 390 & ns \\
\hline 4 cut & 290 & 280 & 280 & ns & 290 & 280 & 280 & ns \\
\hline \multicolumn{9}{|l|}{ Year 1991} \\
\hline 1 cut & 230 & 310 & & $*$ & $240 \mathrm{~b}$ & $330 a$ & $370 a$ & $*$ \\
\hline 2 cut & $290 a$ & $230 \mathrm{ab}$ & $160 \mathrm{~b}$ & $* *$ & $160 \mathrm{~b}$ & $270 \mathrm{a}$ & $260 \mathrm{a}$ & * \\
\hline 3 cut & 250 & 250 & 180 & ns & $180 \mathrm{~b}$ & $250 \mathrm{a}$ & $250 \mathrm{a}$ & $*$ \\
\hline 4 cut & 230 & 210 & 210 & ns & $170 \mathrm{~b}$ & $230 \mathrm{a}$ & $260 a$ & $* *$ \\
\hline \multicolumn{9}{|l|}{ Year 1991} \\
\hline 1 cut & 320 & 390 & & ns & $330 \mathrm{~b}$ & $430 \mathrm{ab}$ & $500 \mathrm{a}$ & * \\
\hline 2 cut & $390 a$ & $320 a$ & $190 \mathrm{~b}$ & $* * *$ & 280 & 310 & 310 & ns \\
\hline 3 cut & 120 & 100 & 170 & ns & 130 & 130 & 150 & ns \\
\hline 4 cut & 100 & 87 & 150 & ns & 70 & 110 & 150 & ns \\
\hline
\end{tabular}

${ }^{* * * \mathrm{P}}<0.001 ;{ }^{* * \mathrm{P}}<0.01 ;{ }^{*} \mathrm{P}<0.05 ;$ ns:not significant.

Table 16. Potash production (kg/ha) of sward in each cut, year and treatment.

\begin{tabular}{|c|c|c|c|c|c|c|c|c|}
\hline$=$ & $\mathbf{N}=0$ & $\mathrm{~N}=30$ & $N=60$ & Sig & $\mathbf{K}=0$ & $K=100$ & $K=200$ & Sig. \\
\hline Year 1989 & \multicolumn{4}{|c|}{ 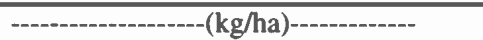 } & \multicolumn{4}{|c|}{--------------------(kg/ha)------------- } \\
\hline 1 cut & 11.0 & 13.8 & & $* *$ & 10.9 & 13.5 & 12.5 & ns \\
\hline 2 cut & $43.7 \mathrm{a}$ & $43.8 \mathrm{a}$ & $14.7 \mathrm{~b}$ & $* * *$ & 69.1 & 73.0 & 93.0 & ns \\
\hline 3 cut & $43.5 b$ & $74.9 \mathrm{a}$ & $74.6 \mathrm{a}$ & $* * *$ & 53.9 & 65.2 & 74.0 & ns \\
\hline 4 cut & $31.2^{\mathrm{a}}$ & $17.0 \mathrm{~b}$ & $17.8 \mathrm{~b}$ & $* * *$ & 19.0 & 22.6 & 24.4 & ns \\
\hline 5 cut & 28.6 & 26.4 & 27.6 & ns & 27.0 & 27.1 & 28.4 & ns \\
\hline \multicolumn{9}{|l|}{ Year 1990} \\
\hline 1 cut & 50.9 & 46.7 & & ns & $23.9 \mathrm{~b}$ & $48.8 \mathrm{ab}$ & $73.9 \mathrm{a}$ & $* * *$ \\
\hline 2 cut & $43.4 b$ & $40.3 b$ & $106.4 \mathrm{a}$ & $* * *$ & 54.6 & 63.9 & 72.7 & ns \\
\hline 3 cut & $46.5 b$ & $64.3 \mathrm{a}$ & $39.1 \mathrm{~b}$ & $* * *$ & $39.7 b$ & $56.9 \mathrm{a}$ & $54.7 \mathrm{a}$ & * \\
\hline 4 cut & $21.3 \mathrm{a}$ & $19.5 \mathrm{~b}$ & $19.3 b$ & $* * *$ & 20.4 & 19.9 & 19.9 & ns \\
\hline \multicolumn{9}{|l|}{ Year 1991} \\
\hline $1 \mathrm{cut}$ & 31.9 & 37.1 & & ns & $22.2 \mathrm{~b}$ & $37.5 \mathrm{ab}$ & $56.6 \mathrm{a}$ & $* * *$ \\
\hline 2 cut & 44.6 & 43.1 & 34.3 & ns & $27.0 \mathrm{~b}$ & $43.9 \mathrm{a}$ & $52.6 \mathrm{a}$ & $* * *$ \\
\hline 3 cut & 29.6 & 27.5 & 24.4 & ns & $23.1 \mathrm{~b}$ & $26.6 \mathrm{ab}$ & $32.1 \mathrm{a}$ & $*$ \\
\hline 4 cut & 28.2 & 22.3 & 24.1 & ns & $18.4 \mathrm{~b}$ & $25.4 \mathrm{ab}$ & $30.9 \mathrm{a}$ & * \\
\hline \multicolumn{9}{|l|}{ Year 1991} \\
\hline $1 \mathrm{cut}$ & 41.2 & 51.5 & & ns & $38.6 \mathrm{~b}$ & $53.8 \mathrm{ab}$ & $77.9 \mathrm{a}$ & $* * *$ \\
\hline 2 cut & $75.6 \mathrm{ab}$ & $97.0 \mathrm{a}$ & $45.6 \mathrm{~b}$ & $* *$ & 70.5 & 66.0 & 81.7 & ns \\
\hline 3 cut & 14.4 & 9.3 & 17.3 & ns & 12.2 & 11.8 & 17.0 & ns \\
\hline 4 cut & $20.8 b$ & $16.3 b$ & $32.1 \mathrm{a}$ & $*$ & 15.3 & 25.1 & 28.8 & ns \\
\hline
\end{tabular}

${ }^{* * * \mathrm{P}}<0.001 ;{ }^{* * \mathrm{P}}<0.01 ; * \mathrm{P}<0.05 ;$ ns:not significant

\section{Conclusions}

A modest rate of $\mathrm{N}$ application is recommended the first year after pasture establishment because legume presence is minimal. In subsequent years fertilization needs appear to depend on legume development affected by growth higher $\mathrm{N}$ applications. Potassium fertilization increased legume content and DM yield with higher crude protein and $K$ in herbage. Legume-rich pastures developed where low $\mathrm{N}$ fertilizer was applied. Mineral content of pastures should take into account the botanical differences among swards arising from fertilization practices.

\section{Literature Cited}

ARC, 1991. AFRC. Technical Committee on Responses to Nutrients, Report 6. A reappraisal of the calcium and phosphorus requirements of sheep and cattle. Nutr. Abstr. Rev.. Ser. B: Livestock Feeds and Feed. 61(9):573-612.

Babnik, D., V. Znidarsic-Pongrac, J. Verbic, and J. Verbic. 1996. The effect of fertilization on the concentration of mineral elements in grasses, forbs and legumes from the permanent karst grassland. Grassl. Science in Europe. 1:373-376.

Berthelsen, H.B., J. Ford, J. Evans, and J.R. Caradus. 1994. Effect of mineral $\mathrm{N}$ on spring growth and $\mathrm{N}$ fixation of white clover lines. Proc. Ann. Conf. Agron. Soc. of New Zealand. 24:37-41.

Castro, P., A. González, and D. Prada. 1990. Simultaneous determination of nitrogen and phosphorus in sward samples (In Spanish), p. 200-207. In: Pastos (ed.) Actas de la XXX Reunión Científica de la Sociedad Española para el Estudio de los Pastos. San Sebastian, Spain.

Chapman, D. F., A. J. Parsons, and S. Schwimming. 1996. Management of clover in grazed pastures: expectations, limitations and opportunities, p. 21-22. In D. R. Woodfield (ed.)White clover: New Zealand's competitive edge. Proc. of a joint symposium between Agron. Society of New Zealand and New Zealand Grassl. Assoc.. Lincoln Univ., Lincoln, New Zealand.

Chevalier, H. 1981. Mixed sward Fertilization (In French). Au service de L'agriculture 20: 1-28.

Clark, D.A. and S.L. Harris. 1996. White clover or nitrogen fertilizer for dairying?, p. 107-114. In D. R. Woodfield (ed.) New Zealand and New Zealand Grassl. Assoc.. Lincoln Univ., New Zealand.

Cox, W.J. 1973. Potassium for pastures. J. Agr. Western Australia 14:3-13.

Dampney, P.M.R. 1992. The effect of timing and rate of potash application on the yield and herbage composition of grass for silage. Grass Forage Sci. 47:280-289.

Davies, A. 1989. The structure of the grass/clover swards and its implications in sward management, p. 1065-1066. In: European Grassland Federation (ed.) 16 Int. Grassl. Congr. Nice, France

Floate, M.I.S., A. Rangley, and F. R. Bolton. 1981. An investigation of problems of sward improvement on deep peat with especial 
reference to potassium responses and interactions with lime and phosphorus. Grass Forage Sci. 36:81-90.

Frame, J. 1990. The effects of nitrogen and potassium fertilizer on the productivity of perennial ryegrass/white clover swards, $p$. 596. In: International Scientific Centre of Fertilizers - CIEC (ed.) Proc. 10 World Fertilizer Congr. of Int. Scientific Centre of Fertilizers (CIEC), Nicosia, Cyprus.

Frame, J. and P. Newbould. 1984. Herbage production from grass/white clover swards, p. 15-35. In: D.J. Thomson (ed.) 16 Occasional Symposium Brit. Grassl. Society. Mainhead, UK.

González, A. 1988. Clover evolution, nitrogen fixation and seasonal distribution of a mixed sward response to Fertilization and grazing, p. 272-276. In: European Grassland Federation (ed.) Proc. 12 General Meeting EGF. Dublin, Ireland

González, A. 1992. Las praderas de gramínea y trébol y la fertilziación nitrogenada en Galicia, p. 383-393. In: Consellería de Agr. (ed.) 100 Años de Investigación Agraria. Xunta de Galicia. Santiago de Compostela, Spain.

González, A., J. Piñeiro, and M. Cropper. 1996. Extending the grazing season. In: Parente, G., J. Frame and S. Orsi (ed.) General Meeting on 'Grassland and land use systems', Grassland Science in Europe, Vol. 1. EGF. Grado, Italy.

Grace, N.D. 1983a. Calcium, p.100-105. In: N.D.Grace (ed.) The mineral requiements of grazing ruminants, 9. N. Z. Soc. of Anim. Prod. Hamilton, New Zealand.

Grace, N.D. 1983b. Magnesium, p. 92-99. In: N.D. Grace (ed.) The mineral requirements of grazing ruminants, 13. N. Z. Soc. of Anim. Prod. Hamilton, New Zealand.

Grace, N.D. 1983c. Phosphorus, p.106-112. In: N.D. Grace (ed.) The mineral requirements of grazing ruminants, $15 . \mathrm{N}$. Z. Soc. of Anim. Prod. Hamilton, New Zealand.
Hopkins, A., A.H. Adamson, and P.J. Bowling. 1994. Response of permanent and reseeded grassland to fertilizer nitrogen. 2 . Effects on concentrations of $\mathrm{Ca}, \mathrm{Mg}, \mathrm{K}, \mathrm{Na}$, $\mathrm{S}, \mathrm{P}, \mathrm{Mn}, \mathrm{Zn}, \mathrm{Cu}, \mathrm{Co}$ and $\mathrm{Mo}$ in herbage at a range of sites. Grass Forage Sci., 49,9-20.

Kabata, A. and H. Pendías. 1984. Trace elements in soil and plants. CRC Press Inc. Boca Ratón, Fla.

Loué, A. 1988. Los microelementos en agricultura. Ediciones Mundi-Prensa. Madrid, Spain.

Meister, E. and J. Lehmann. 1985. Mutual influence of temperate legumes and grasses grown in associations at different nitrogen levels, p. 585-587. In: Science Council of Japan and Japanese Society of Grassland Science (ed.) Proc. of the 15 Int. Grassl. Congr. Kyoto, Japan.

Metson, A.J. and W.M.H. Saunders. 1978. Seasonal variations in chemical composition of pasture. I. Calcium, magnesium, potassium, sodium and phosphorus. New Zealand J. Agric. Research, 21:341-353.

Monterroso, M.C. 1995. Characterization of edaphogeochemical processes in a dump of lignite in a environmental restoration process (In Spanish). PhD Tarsis. Universidade de Santiago de Compostela, Santiago de Compostela, Spain.

Mosquera, M.R. and A. González, 1997. Nitrogen and potassium use to increase the production and persistence de white clover (In Spanish). Pastos 27(2): 207-218.

Mosquera, M.R., A. González and A. Rigueiro. 1999. Ecología y manejo de praderas. Ministerio de Agric. Santiago de Compostela-Madrid, Spain.

Mosquera, M.R., A. González, and T. Brea.1992. Effect of the dose and application time of the first nitrogen in a mixed sward (In Spanish), p. 185-193. In: Sociedad Española para el Estudio de los Pastos (ed.) XXXII Reunión Científica de la Sociedad Española para el Estudio de los Pastos. Pamplona, Spain.
Norton, B.W. 1982. Differences between species in forage quality, p. 91-109. In: J.B. Hacker (ed.) Proc. of an Int. Symposium held at St. Lucia, 1981. Nutritional Limits to Animal Production from Pastures?. Queensland, Australia

NRC. 2001. Nutrients requirements of dairy cattle. Seventh Revised edition Update, 1989:National Research Council, 408 pp. Washington D.C., United States.

Reid, R.L. and D.J. Horvath. 1980. Soil chemistry and mineral problems in farm livestock. A review. Animal Feed Sci. Tech. 15:95-167.

Robin, C., L. Shamsun-Noor, and A. Guckert. 1989. Effect of potassium on the tolerance to PEG-induced water stress of two white clover varieties (Trifolium repens L.) Plant and Soil 120:153-158.

Rodríguez, M. and M. Pinto. 1987. Fertilization nitro-fosfo-potásica on naturals grasslands in Basque Country (in Spanish). Pastos, 17(1-2):203-218.

Simpson, D., D. Wilman, and R. Adams. 1988. Response of white clover and grass to applications of potassium and nitrogen a potassium deficient hill soil. J. Agr. Sci. 10:159-167.

Whitehead, D.C. 1995. Grassland Nitrogen. CAB Int., 397 pp. Wallingford, Oxon United Kingdom.

Willman, D., G.H. Acuña, and P. Joy Michaud. 1994. Concentrations of $N, P, K$, $\mathrm{Ca}, \mathrm{Mg}$ and $\mathrm{Na}$ in perennial ryegrass and white clover leaves of different ages. Grass Forage Sci.. 49:422-428. 